\title{
KARAKTERISTIK DAN POLA PENGOBATAN PASIEN KANKER PAYUDARA DI RSUD ABDUL WAHAB SJAHRANIE
}

\author{
Marsanti $^{1}$, Christina Ade Febriana ${ }^{2} *$, Arsyik Ibrahim ${ }^{2}$, Dewi Rahmawati ${ }^{2}$ \\ ${ }^{1}$ RSUD Abdul Wahab Sjahranie Samarinda \\ ${ }^{2}$ Fakultas Farmasi Universitas Mulawarman, Samarinda, Kalimantan Timur \\ *Email: adhe.christina09@gmail.com
}

\begin{abstract}
Breast cancer is one type of deadly cancer for women. This study aims to determine the characteristics and patterns of treatment of breast cancer patients at hospitalization installation in General Hospital Of Abdul Wahab Sjahranie Samarinda. The method used in this research is non-experimental descriptively method. The study involved 43 patients who subsequently characterized by sex and age, then grouped patterns of treatment performed. The results obtained as much as $95 \%$ of patients were female and 5\% of patients were male sex. Ages 20 to 39 years were $45 \%$ and 40 to 50 years were $55 \%$. Therapy for chemotherapy treatment was $68 \%$, for surgery was $18 \%$ and combination of surgery and chemotherapy were $14 \%$, and then the incompatibility of this therapy by $39.53 \%$ and appropriateness of therapy by $60.47 \%$. Selection of drugs for the treatment to breast cancer with the highest drug combination resulted in a combination of drugs gemcikal - braxel as much as $65.71 \%$. While the combination of nevelbi - braxel as much as 14:29\% and on cyclophosphamide - doxorubicin - 5 fluorouracil was 20\%. From these results the obtained data shows that inappropriate therapy as much as 11,54\% and suitability therapy as much as $88.46 \%$.
\end{abstract}

Keywords : breast cancer, treatment pattern, ages

\begin{abstract}
ABSTRAK
Kanker payudara merupakan salah satu jenis penyakit kanker yang mematikan bagi wanita. Penelitian ini bertujuan untuk mengetahui karakteristik dan pola pengobatan pasien kanker payudara di instalasi rawat inap di RSUD Abdul Wahab Sjahranie Samarinda. Metode penelitian yang digunakan berupa metode noneksperimental secara deskriptif. Penelitian ini melibatkan 43 orang pasien yang kemudian dikarakterisasikan berdasarkan jenis kelamin dan usia, kemudian dikelompokkan pola pengobatan yang dilakukan. Hasil yang di peroleh sebanyak $95 \%$ pasien berjenis kelamin perempuan dan 5\% pasien berjenis kelamin laki-laki. Usia 20 sampai dengan 39 tahun sebanyak $45 \%$ dan 40 sampai dengan 50 tahun sebanyak 55\%. Terapi pengobatan yaitu untuk kemoterapi sebanyak $68 \%$, untuk pembedahan terdapat $18 \%$ dan kombinasi antara pembedahan dan kemoterapi adalah $14 \%$, maka ketidak sesuaian terapi ini sebesar $39.53 \%$ dan kesesuaian terapi sebesar $60.47 \%$. Pemilihan obat untuk terapi kanker payudara dengan kombinasi obat tertinggi dihasilkan pada kombinasi obat gemcikal - braxel sebanyak 76.64\%. Sedangkan kombinasi nevelbi braxel sebanyak $14.29 \%$ dan pada cyclophosphamide - dexorubin - 5 fluoro uracil $20 \%$. Dari hasil ini didapatkan ketidak sesuaian terapi sebanyak $11.54 \%$ dan kesesuaian sebanyak $88.46 \%$.
\end{abstract}


Kata Kunci: Kanker payudara, pola pengobatan, usia.

\section{PENDAHULUAN}

Kanker merupakan penyakit dengan karakteristik adanya gangguan atau kegagalan mekanisme multipikasi pada organisme multiseluler sehingga terjadi perubahan perilaku sel yang tidak terkontrol (Nurwijaya, 2009).

Tumor adalah suatu pertumbuhan sel-sel abnormal yang tumbuh tidak terkontrol. Tumor dibagi menjadi 2 yaitu tumor jinak dan tumor ganas. Tumor jinak yaitu tumor yang tumbuh terbatas pada organ tersebut, tumbuhnya lambat dan tidak menyebar ke organ lain. Tumor ganas yaitu disebut dengan kanker, tumbuh dengan cepat dan menyebar ke organ lain (Nurwijaya, 2009).

Kanker payudara adalah pertumbuhan sel payudara yang tidak terkontrol lantaran perubahan abnormal dari gen yang bertanggung jawab atas pengaturan pertumbuhan sel. Secara normal, sel payudara yang tua akan mati, lalu digantikan oleh sel yang lebih baik. Regenerasi sel sepertu ini berguna untuk mempertahankan fungsi payudara. Pada kasus kanker payudara, gen yang bertanggung jawab terhadap pengaturan pertumbuhan sel termutasi (Rasjidi, 2010).

Gejala klinis kanker payudara bisa berupa benjolan pada payudara yang tidak terasa nyeri. Semula benjolan itu kecil dan lama kelamaan benjolan ini semakin besar lalu melekat pada kulit, sehingga menimbulkan perubahan pada kulit dan puting payudara. Itulah yang membuat puting payudara tertarik kedalam, serta berwarna merah muda atau kecokelatan sampai mengerut atau timbul borok pada payudara. Semakin lama, borok akan semakin besar dan dalam dan inilah yang akan menghancurkan seluruh payudara (Rasjidi, 2010).

Di Indonesia, penyakit kanker menempati urutan nomor 5 dan diperkirakan angka kejadian pertahun 100 per 100.000 penduduk. WHO menyatakan, pada tahun 2005 diperkirakan ada 9 juta orang yang meninggal dunia karena kanker dan tahun 2030 diperkirakan ada 11.4 juta kematian karena kanker (Depkes RI, 2003).

Kanker payudara merupakan salah satu penyakit paling mematkan bagi wanita. Menurut WHO 8 hingga 9\% wanita akan mengalami kanker payudara. Hal ini menjadikan kanker payudara sebagai kanker yang paling banyak ditemui pada wanita. Kanker payudara merupakan penyebab utama kematian pada wanita (Sandina, 2011).

Bedasarkan berbagai kasus tersebut diatas dapat memberikan gambaran bahwa kasus penyakit kanker payudara perlu diberikan penanganan dan perhatian yang serius karena resiko kematian yang ditimbulkan. Oleh karena itu, dalam hal ini peneliti bertujuan untuk mengkaji karakteristik dan pola pengobatan pada pasien kanker payudara terutama dalam pola pengobatan yang dilakukan di Rumah Sakit Umum Abdul Wahab Sjahranie Samarinda.

\section{METODE PENELITIAN}

Jenis penelitian yang digunakan adalah penelitian deskriptif dengan pendekatan retrospektif, dengan menganalisis catatan rekam medik pasien kanker payudara yang melakukan terapi bulan Januari sampai Desember 2015 di RSUD Abdul Wahab Sjahranie Samarinda, Kalimantan Timur.

\section{PERALATAN}

Peralatan yang digunakan disajikan pada tabel 1. 
Tabel 1. Peralatan penelitian

\begin{tabular}{|c|c|c|}
\hline No. & Alat & Kegunaan dalam penelitian \\
\hline 1. & Alat tulis & $\begin{array}{l}\text { Sebagai alat untuk menulis data yang diperoleh dari observasi } \\
\text { dan rekam medik }\end{array}$ \\
\hline 2. & Buku catatan & $\begin{array}{l}\text { Sebagai media penulisan data-data yang bersumber dari hasil } \\
\text { observasi dan rekam medik }\end{array}$ \\
\hline 3. & Laptop & Sebagai alat untuk mengolah data dan menganalisis data \\
\hline 4. & Rekam Medik & Sebagai sumber data sekunder pasien yang akan diteliti \\
\hline
\end{tabular}

\section{PROSEDUR}

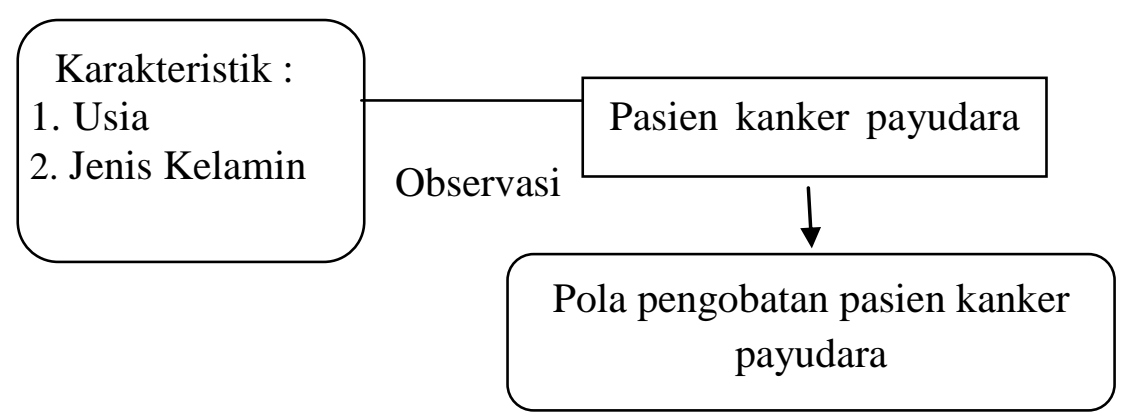

Gambar 1. Prosedur Pengumpulan Data

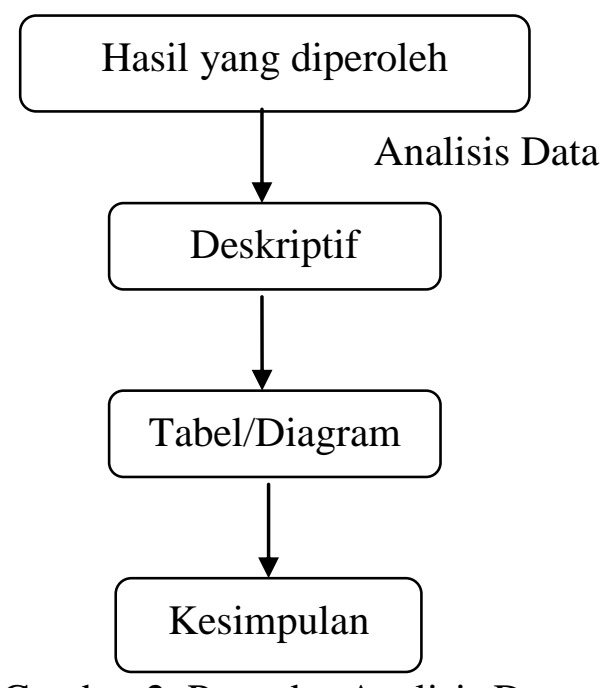

Gambar 2. Prosedur Analisis Data

\section{HASIL DAN PEMBAHASAN}

Pasien kanker payudara yang menjadi sampel dalam penelitian ini sebanyak 43 orang pasien dengan berbagai pola pengobatan yang dijalani. Kemudian pasien dikarakterisasi berdasarkan jenis kelamin dan usia. Sebanyak 41 pasien berjenis kelamin perempuan dan 2 pasien berjenis kelamin laki-laki. 
Tabel 1. Distribusi pasien kanker payudara berdasarkan jenis kelamin

\begin{tabular}{ccc}
\hline Jenis Kelamin & Jumlah & Persentase \\
\hline Laki-laki & 2 & $4.7 \%$ \\
Perempuan & 41 & $95.3 \%$ \\
\hline Total & $\mathbf{4 3}$ & $\mathbf{1 0 0 \%}$ \\
\hline
\end{tabular}

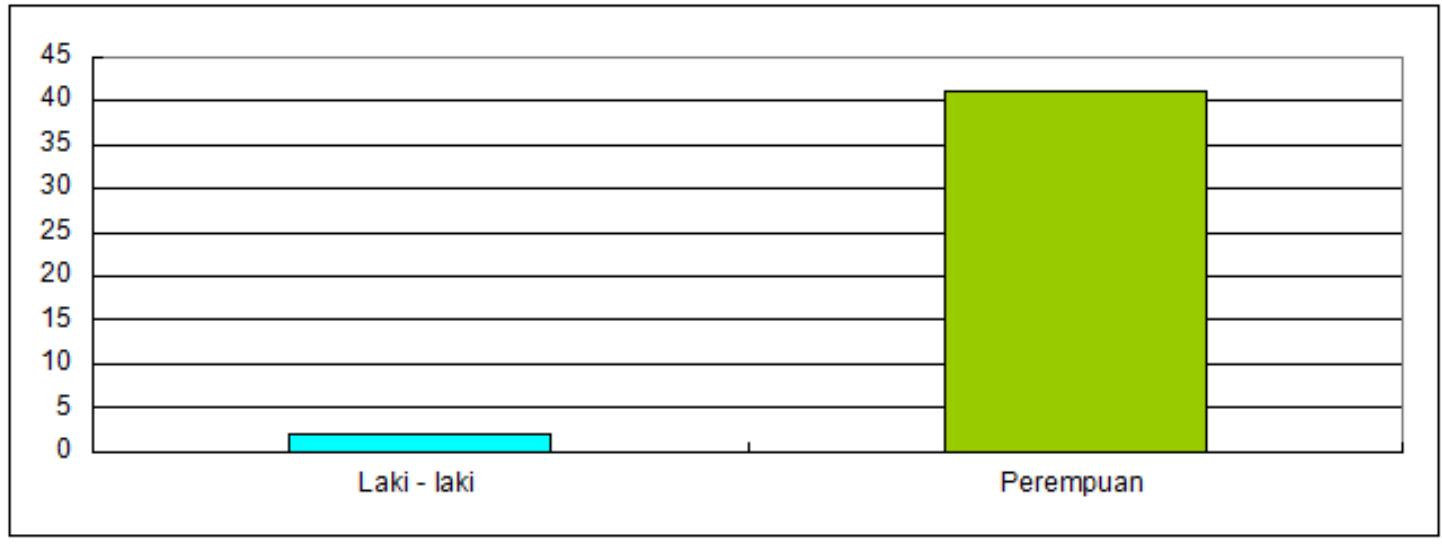

Gambar 3.Distribusi pasien kanker payudara berdasarkan jenis kelamin

Berdasarkan Tabel 1 diperoleh bahwa sebagian besar responden merupakan perempuan (95\%). Hal ini berkesusuaian dengan yang dilaporkan oleh Paradila (2013) bahwa insiden kanker payudara tertinggi terjadi pada perempuan, dan hanya sebagian kecil terjadi pada laki-laki. Farktor penyebab kanker payudara adalah usia menarke, kelahiran pertama, faktor genetik, paparan radiasi dan hormon. Pada pria kanker payudara dapat terjadi oleh karena faktor tersebut, tetapi biasa ditemukan pria yang mengidap kanker payudara karena memiliki sindrom Klinefelter dimana ini merupakan sindrom kelainan genetik.

Karakteristik pasien kanker payudara yang menjadi sampel penelitian ini sebanyak 12 pasien berusia antara 20 sampai dengan 39 tahun, dan sebanyak 31 pasien berusia antara 40 sampai dengan 50 tahun.

Tabel 2. Distribusi pasien berdasarkan usia

\begin{tabular}{ccc}
\hline Usia & Jumlah & Persentase \\
\hline $20-39$ tahun & 12 & $27.97 \%$ \\
$40-50$ tahun & 31 & $72.03 \%$ \\
\hline Total & $\mathbf{4 3}$ & $\mathbf{1 0 0 \%}$ \\
\hline
\end{tabular}




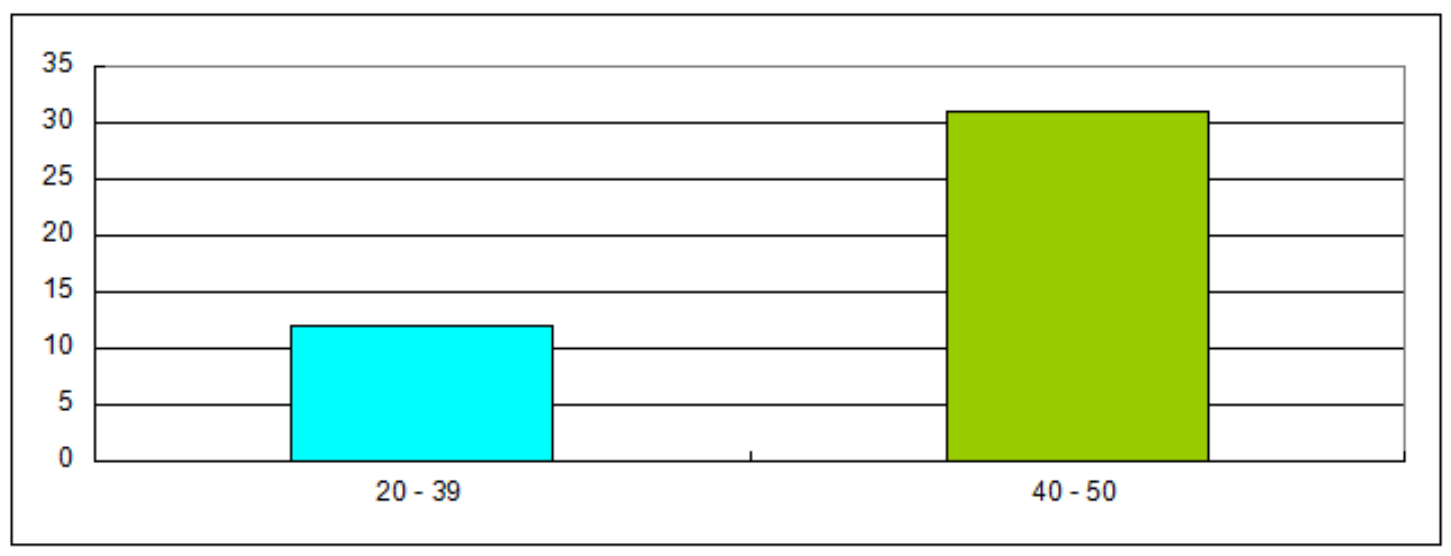

Gambar 4. Distibusi pasien berdasarkan usia

Berdasarkan Tabel 2 diperoleh bahwa sebagian besar responden berusia antara 40 sampai dengan 50 tahun (73\%). Hal ini berkesesuaian dengan yang dilaporkan oleh Robbins (2008) bahwa sekitar 60\% kanker payudara terjadi pada wanita diatas 40 tahun. Pada usia 40-50 tahun merupakan masa yang memungkinkan seorang wanita terkena kanker payudara maka wanita usia $>40$ tahun dimana pada masa ini merupakan usia yang rentan terkena kanker payudara, karena semakin tua usia seseorang, maka semakin meningkat risiko terjadinya kanker payudara. Meningkatnya risiko kanker payudara pada usia lanjut merupakan gabungan dari meningkatnya dan bertambah lamanya waktu pemaparan terhadap karsinogen serta makin melemahnya sistem kekebalan tubuh akibat usia. Hasil penelitian juga menujukkan bahwa terdapat pasien usia 20-39 tahun (27\%) diharapkan dapat melaksanakan pemeriksaan rutin terhadap kesehatannya terutama pemeriksaan rutin gejala kanker payudara sehingga jika penyakit ini ditemukan dengan cepat dan mudah ditanggulangi jika pada stadium awal jika dibandingkan ditemukan pada stadium lanjut.

Pola pengobatan pada pasien kanker payudara lebih sering menggunakan terapi kombinasi yaitu kemoterapi dan pembedahan. Tujuan terapi kombinasi adalah pada pembedahan untuk mengangkat sel kanker kemudian dilanjutkan dengan kemoterapi untuk memusnahkan sel kanker yang mungkin tidak terangkat atau masih tertinggal pada organ target.

Tabel 3. Distribusi pasien berdasarkan pola pengobatan

\begin{tabular}{ccc}
\hline Pola Pengobatan & Jumlah & Persentase \\
\hline Kemoterapi & 8 & $20.93 \%$ \\
Pembedahan & 9 & $18.6 \%$ \\
Kemoterapi - pembedahan & 26 & $60.47 \%$ \\
\hline Total & $\mathbf{4 3}$ & $\mathbf{1 0 0 \%}$ \\
\hline
\end{tabular}

Berdasarkan Tabel 3 diperoleh sebagian besar responden melakukan terapi kombinasi kemoterapi dan pembedahan (59\%). Sedangkan terapi pembedahan dan kemoterapi cukup sedikit yaitu pada pembedahan 18\% dan pada kemoterapi 23\%. Pada panduan Penatalaksanaan Pengobatan Kanker Payudara (2014) pengobatan kanker payudara lebih disarankan untuk melakukan terapi kombinasi antara pembedahan dan kemoterapi dan bila perlu dilakukan terapi radiasi. 


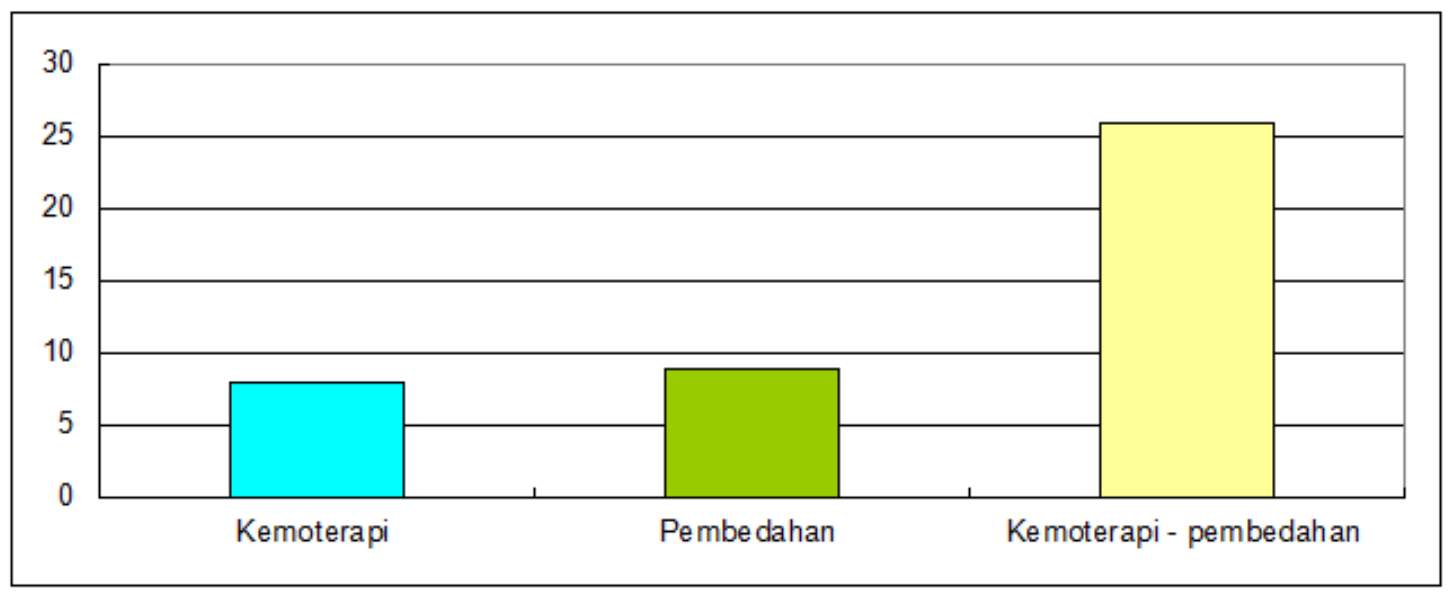

Gambar 5. Distribusi pasien berdasarkan pola pengobatan

Pengobatan kemoterapi pada kanker payudara lebih sering menggunakan obat yang bekerja pada bagian yang berada dari proses metabolisme sel, sehingga akan meningkatkan kemungkinan dihancurkannya jumlah sel kanker.

Pola pengobatan kemoterapi pada pasien kanker payudara di RSUD Abdul Wahab Sjahranie berdasarkan golongan obat dan jenis obat yang digunakan pasien ditabulasikan pada tabel 4.

Tabel 4. Distribusi pasien berdasarkan golongan obat

\begin{tabular}{ccc}
\hline Kombinasi Obat & Jumlah & Persentase \\
\hline Gemcikal - Braxel & 23 & $76.64 \%$ \\
Nevelbi - Braxal & 4 & $11.76 \%$ \\
Cyclophospamide - Dexorubin - 5 Fluoro Uracil & 7 & $11.6 \%$ \\
\hline Total & $\mathbf{3 4}$ & $\mathbf{1 0 0 \%}$ \\
\hline
\end{tabular}

Berdasarkan Tabel 4 diperoleh bahwa hasil golongan obat dan jenis obat yang diberikan pasien kanker serviks menggunakan pengobatan kombinasi. Kombinasi obat tertinggi dihasilkan pada kombinasi obat gemcikal - braxel sebanyak 23 responden (76\%), dimana kombinasi ini digunakan untuk menurunkan kadar kreatinin pasien kanker payudara yang lebih dari batas kadar normal kreatinin $(0,5-1 \mathrm{mg} / \mathrm{dl})$ atau mengalami kerusakan ginjal parah, sedangkan hasil kombinasi terendah yaitu kombinasi nevelbi braxel sebanyak 4 responden (11.76\%), dimana kombinasi ini digunakan untuk menaikkan kadar kreatinin pasien kanker serviks yang kurang dari batas kadar normal kreatinin (0,5-1 $\mathrm{mg} / \mathrm{dl}$ ) atau mengalami kerusakan ginjal ringan (Guidline, 2013). dan kombinasi cyclophospamide - dexorubin - 5 fluoro uracil sebanyak 7 responden $(11.6 \%)$ (NCCN, 2013).

Kombinasi nevelbi - braxel ini digunakan karena braxel bekerja pada fase sintesis DNA (fase S) dan nevelbi bekerja pada fase pembelahan sel (fase M), dimana siklus sel otomatis akan terganggu dan akan menginduksi suatu apoptosis (kematian sel). Sehingga kombinasi braxel dan nevelbi ini akan saling menguatkan dan meningkatkan efektifitas kemoterapi terhadap kanker yang memiliki sifat toksik yang lebih ringan (Perbowo, 2008). 


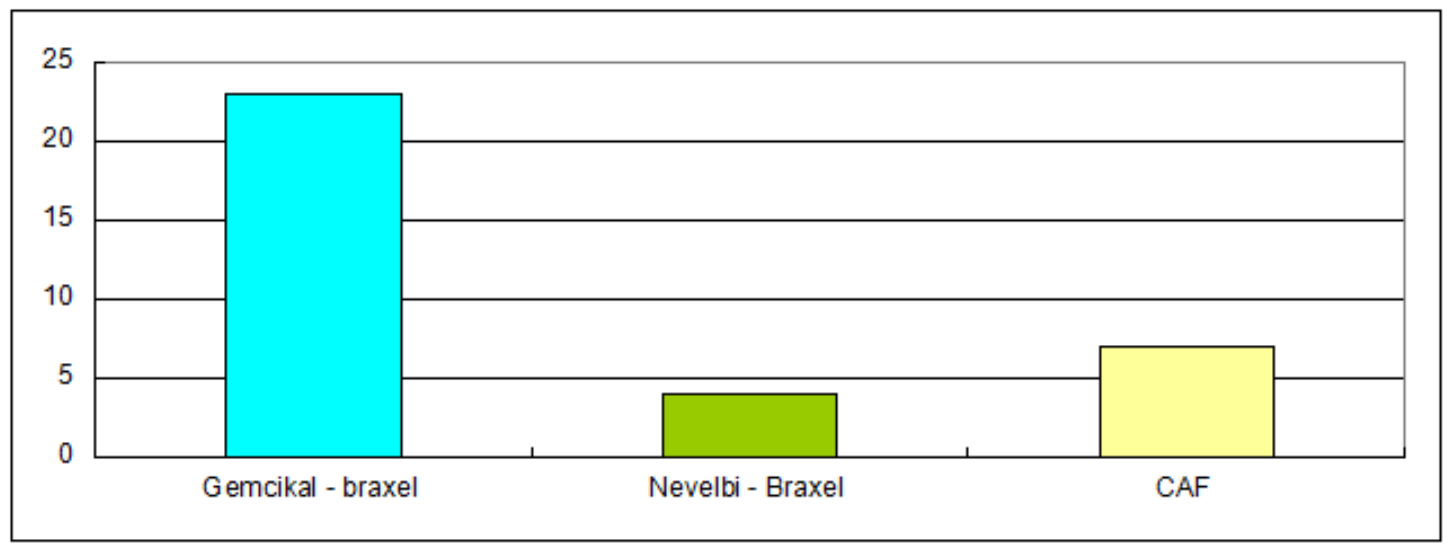

Gambar 6. Distribusi pasien menurut kombinasi obat

Kombinasi Cyclophospamide - Dexorubin - 5 Fluoro Uracil ini digunakan karena cyclophospamide bekerja pada fase replikasi DNA (fase G1 dan fase G2), dexorubin bekerja pada fase sinteseis DNA dan fase pembelahan sel (fase $S$, fase $\mathrm{M}$ ), 5 fluoro uracil bekerja pada fase replikasi DNA dan fase pembelahan sel (fase G2, fase M), dimana siklus sel otomatis akan terganggu dan akan menginduksi suatu apoptosis (kematian sel). Sehingga kombinasi cyclophospamide-dexorubin-5 fluoro uracil ini akan saling menguatkan dan meningkatkan efektifitas kemoterapi terhadap kanker yang memiliki sifat toksik yang lebih ringan (Lucida, 2011).

\section{KESIMPULAN}

Dari hasil penelitian yang dilakukan ditarik kesimpulan bahwa :

1. Berdasarkan jenis kelamin perempuan lebih beresiko mengalami kanker payudara (95.3\%) dari pada laki-laki (4.7\%)

2. Berdasarkan usia pada usia 40 sampai dengan 50 tahun lebih beresiko mengalami kanker payudara (72.03\%) dari pada pasien usia 20 sampai 39 tahun $(27.97 \%)$

3. Pola pengobatan yang paling banyak dilakukan adalah kombinasi kemoterapi dan pembedahan yaitu $60.47 \%$

4. Golongan obat yang paling banyak digunakan yaitu kombinasi gemikal dan braxel sebanyak $76.64 \%$

\section{UCAPAN TERIMA KASIH}

Terima kasih kepada pihak DIKLIT (Bidang Pendidikan dan Penelitian), kepala ruangan rekam medik atas perizinannya dan kerja samanya selama peneliti melakukan peneltian disana.

\section{DAFTAR PUSTAKA}

1. Depkes RI. 2003. Pedoman Nasional Perawatan, Dukungan dan Penngobatan bagi ODHA. Direktorat Jendral Pemberantasan Penyakit Menular dan Penyehatan Lingkungan Depkes RI : Jakarta

2. Fauzee NJS, Dong Z, Wang YL. 2011. Taxanes. Promising anti-cancer drugs: Asian Pacific

3. Kushi, Michio. 1982. Cancer and Hearth Disease the Macrobiotic Approach to Deggenerative Disorders. Japan Publication,INC: Tokyo

4. Foundation. NHS Trust. 2012.Chemotherapy Protocols. Journal The Clatterbridge Cancer Centre NHS Foundation Trush. Volume 10 Number 10 
5. Prandana, Dhani Arief.2013. Pasien Kanker di RSUD H.Adam Malik Medan tahun 2011. Jurnal FK USU volume 1 nomor 2

6. Robbins, dkk. 2008. Buku Ajar Patologi Edisi 7. Penerbit Buku Kedokteran EGC. Jakarta. 